\title{
Influence of ethnicity and religion in Nigerian elections and the imperative of media intervention
}

\begin{abstract}
This study examines the influence of ethnicity and religion on the voting patterns of the Nigerian electorate. The paper employed the content analysis approach being the research method to evaluate the 2015 presidential election, and found that ethnicity played a major role in the election. Since democracy is a game of numbers, it might be relatively difficult ever having a Nigerian President of an Igbo origin without the support of the other ethnic nationalities in the country. This is because the Igbo Community falls within the category of the minority regions in terms of population. So, to create the platform that would enable the members of both the major and the minority ethnic groups to serve as the president of Nigeria, the paper recommends among other things that the office of the Nigerian president be rotated among the six geo political zones as earlier recommended by Chief Anthony Enaharo, architect of the six-geo-political zones in the Nigerian politics. In addition, the paper urges the media to support the formation of an inclusive government, cutting across tribes and religion in the country to reduce the negative impact of ethnicity and religion in the country.
\end{abstract}

Keywords: media, ethnicity, religion, election, colonialist constitutions, clifford constitution, multi-national oil companies, pluralist model
Volume I Issue 3 - 2017

\author{
Godwin Ehiarekhian Oboh \\ Department of Mass Communication, Benson Idahosa \\ University, Nigeria
}

\begin{abstract}
Correspondence: Godwin Ehiarekhian Oboh, Department of Mass Communication, Benson Idahosa University, Nigeria,
\end{abstract} Email ehiarekhian2007@yahoo.com

Received: June 14, 2017 | Published: September 0I, 2017
Abbreviations: PDP, people's democratic party; APC, all progressives congress of nigeria; INEC, independent national electoral commission; CIS, commonwealth of independent states; USSR, union soviet socialist republic; RCCG, redeemed christian church of god

\section{Introduction}

Nigerian Government has successfully conducted the 2015 presidential elections despite the failure the country recorded in the use of card reader that was initially acquired by the Independent National Electoral Commission (INEC) to ensure that only the registered and accredited electorate voted in the elections. Nevertheless, it is very easy for anyone to blame the federal government for failing to conduct very credible elections except for those that understood the influence of ethnicity and religion in the Nigerian politics. It could be recalled that the present Nigerian political system evolved from the British colonialist constitutions. So, when the European guided political philosophy was eventually formulated as a paradigm for development in Nigeria, the leaders soon discovered that the model was essentially abstract in nature as it paid no attention to the historical specificity of the people, but treated development as something that was no way connected to the Nigerian peoples and culture. ${ }^{1}$ In the series of the colonialist constitutions, the Clifford Constitution of 1922 made it possible for Nigerian citizens to elect their own representatives into the legislative council in Lagos, the Bourdillion Constitution of 1939 created the platform for regional government, the Richard Constitution of 1945 offered Nigerians a better platform to participate and discuss their own affairs, the Macpherson Constitution of 1951 established a central Legislative and Executive council for the entire country, the Lyttleton Constitution of 1954 made Nigeria a federal state, while the 1960 Constitution granted political independence to Nigeria. ${ }^{2}$ Although ethnicity has always been a major impediment to the peace and development of Nigeria, its effect was not as pronounced as it is today.

In 1957, the British Government set up the Willink Commission named after the Harry Willink and former Vice-Chancellor of the Cambridge University to investigate the fear that was being expressed by some of the minority ethnic groups in the country following the overbearing attitudes of the major ethnic nationalities in Nigeria. The commission having carefully investigated the issue, recommended among other things: the creation of a special area for the Ijaws (Trust Territory), designation of Edo and Calabar as minority areas, a unified police force, a central prison system for the entire country, and the promotion of the members of the minority groups to the position of power in order to balance any inequity in power sharing in the Nigerian politics. Regrettably, the recommendations made by the commission were not implemented in full. It is worth noting that Ken Saro Wiwa, renowned environmentalist and civil right activist, was killed under the leadership of General Sanni Abacha following the determination by Saro-Wiwa to liberate the Ogoni Community from state-imposed poverty being the aftermath of the protracted oil exploration and exploitation of the region by the transnational oil companies. Corroborating this view, Ewhrudjakpor et al. ${ }^{3}$ noted that: "as a result of these multi-national oil companies' activities, things are no longer the same in the various oil bearing communities in Nigeria. The people also are no longer at ease." Prior to the death of Ken Saro Wiwa and the nine other Ogoni leaders, the proposal converting Ogoni community into a trust territory had already attained the status of an agenda at the International Court of Justice in Hague, following the petition filed by the Ogoni community on the allegation of the marginalization of the Ijaw community by the federal government.

It could be recalled that the British colonialists had wanted to delay the process leading to the Nigerian political independence to enable them have enough time to address the problem of ethnicity and religion in the country based on the recommendations by the Willink Commission. But the Nigerian nationalities were rather too in a hurry, so they were not ready to accept any condition that would delay Nigeria political freedom beyond October 1960. So, religion and ethnicity today have become the two major sources of conflict in the Nigerian politics. This may account for why the more established democratic 
nations tend to relate to the issues regarding religion and ethnicity with a sense of caution. Nigeria is among the leading countries today exporting Christianity to the more established democratic nations of the world. Nonetheless, some people are wondering the basis upon which religious leaders can logically convince the western world to accept religion as a part of state practice considering its implications. However, religious institutions still remain one of the most reliable custodians of moral values in society, so any country that rejects the teaching and practice of accredited religious institutions may find it difficult providing the moral platform for the social conduct of its citizens. So, religion and ethnicity can be deployed to play a functional role in the peace and development of society. Therefore, the central objective of the study is to show how religion and ethnicity influenced the voting pattern of the Nigerian electorate in the 2015 presidential election, and possibly suggests ways the media as emerging power blocs can reduce the negative influence of cultural politics to pave the way for an inclusive government in the country.

\section{Culture and conflicts in politics}

The United Nations and the leaders of the international community now spend more time addressing the conflicts arising from ethnicity and religion in Africa, Asia and the East European countries than the time they spend on other issues. Atubi et al. ${ }^{4}$ noted that: " since September 19, 2002, Cote d' Ivoire has been gripped by an internal conflict that has paralyzed the economy, split the political leadership, and illuminated the stark polarization of Ivorian society along ethnic, political and religious lines." Syria, Afghanistan, Libya, Morocco, Chad, Sudan, Rwanda, Egypt and Burundi have had their share of intra/inter-tribal conflicts. ${ }^{5}$ Observes that: "Among the raft of changes that have confronted the international community in the decade which followed the events of 1989, there exists an apparent dichotomy between, on the one hand, the collapse of the nation state (at least in some countries) and the reassertion of national identity elsewhere". Virtually all the countries in the West Africa sub-region, including Nigeria, have passed through the tunnel of crisis emanating from intercultural and religious conflicts. Culture is one of those imperceptible elements defining the identity of a people. It describes the character of a community, and influences the attitudes and behaviour of the people. $^{6}$

Each cultural nationality in Nigeria has a set of values that distinguishes one community from the other, and no community is ready to compromise its cultural identity in the interests of the other communities $\mathrm{Omu}^{7}$ noted that ethnicity usually undergoes an evolutionary process whereby it starts as a latent and accommodating feeling, and later become instigated or propelled as a weapon of hostility, conflict and bitter tensions. What Omu perhaps forgot to include is that the hostility and conflicts that later arise from the self determinism of an ethnic nationality may probably be associated with the effort by the people to promote and sustain their ethnic identity in the face of other contending cultural paradigms. In an earlier study, Okechukwu ${ }^{8}$ affirms that: "It is axiomatic to posit that nationalism and ethnic differences contributed to the final breakup of the Union Soviet Socialist Republic (USSR), and have also contributed to plaguing the Commonwealth of Independent States (CIS), especially Russia.” So, culture plays a major role in the construction of the meaning underlining the attitudes and behaviour of the members of a community. "Some cultural and communication patterns are relatively stable according to, ${ }^{9}$ while other aspects of cultural identification dynamically shift over time." The major problem facing Nigeria today is the inability of the federal government to resolve the issues regarding ethnicity and religion. Although Nigeria is a secular state, the country shares the attributes of Christianity and Islamic religion, depending on the religious inclination of the incumbent president and state governors.

\section{Rationale}

Ethnicity and religion have considerable influence on the voting patterns of the Nigerian electorate. Although the federal government often stresses the need for the citizens to put national interest above ethnic and religious considerations, yet there is no politician in Nigeria who will win an election without the support of the members of his or her ethnic nationality. This is why most politicians tend to give priority attention meeting needs of their ethnic nationalities even at the detriment of national interest. Unfortunately, the present Nigerian political system has no provision for the members of the minority ethnic groups becoming president of Nigeria without the support of the major ethnic nationalities in the country. This might be one of the reasons for the ongoing agitations for secession and the call for an amendment on the present structure of the Nigerian political system by some ethnic groups in the country. So the press as an ombudsman can serve as a nexus reconciling the dividing lines between and among ethnic nationalities and religious institutions in Nigeria, thus explaining the rationale for the study.

\section{Theory}

Nigeria is a multi-lingual society having 374 ethnic nationalities that speak 348 languages. ${ }^{10}$ It is a part of the Nigerian culture for children to show respect to their parents and the elderly ones in society, but the way and manner this respect is demonstrated among Nigerians differ from one tribe to the other. Nevertheless, the ancestral beliefs of many communities in Nigeria are gradually being eroded and replaced with modern values consequent upon the assumption that most African traditional religions are shrouded in mysteries. In the view of Manderson ${ }^{11}$ "Local cultures often adopt traditional forms (folks music, oral histories, pagan rites and festivals) to preserve ancient customs against new theories, which were making important changes in the structure of legal subjectivity," justifying why religion forms the basis of human idiosyncrasies in many African and the Asian world.

For example, the Redeemed Christian Church of God (RCCG) is one of the leading Pentecostal Churches in Nigeria. The headquarters of the Church is located in Ogun State, and the General Overseer of the Church, Pastor Enoch Adeboye, is a Nigerian of a Yoruba origin. Yet, the Church has worship centres across the country. Similarly, the head of the Sokoto Caliphate, Alhaji Sa'adu Abubakar, is the head of the Islamic religion in Nigeria. Islam has worship centres in all the states of the federation. The intercultural communication among Nigerians who are members of the same religion seems to be very harmonious notwithstanding their tribal differences, whereas most religious conflicts in Nigeria emanate from the intercultural communication between persons of different religious backgrounds. This is why it may be necessary for the Nigerian government to imbibe the concept of the 'Third Cultures'. According to McEwan et al. ${ }^{12}$ "Third cultures, a concept developed by Casmir (1978, 1997), are formed when individuals from two or more cultures create a new hybrid culture, containing the components of each individual culture while developing unique cultural characteristics." This concept when fully internalized by the citizens may enhance the social integration among the people and create the basis for the effective social mobilization of the citizens 
toward achieving laudable objectives in the interest of the peace and development of society. "Culture and communication, according to, ${ }^{13}$ are intimately linked. Signs and symbols are communicated through language and through cultural artefacts. Each culture also has its own worldview or expectations about its cultural artefacts, human conduct and identity." It is the variations in the expectations of the people of different culture and religion that often creates the basis for the frictions that we witness intermittently in society.

Nevertheless, it is often the way and manner the media report on the initial disagreements arising from the intercultural communications between people of different culture and religion that normally accentuates the tempo of conflict in society. As Kaylor ${ }^{14}$ "The Media depictions of Jesus are important cultural images to consider due to the symbolic power of shaping Jesus to look and talk a certain way or address specific issues. Thus, Jesus often is remade to fit the cultural beliefs and norms of those crafting his image." Unfortunately, some journalists have a very narrow view knowing that Nigeria is a pluralistic society, which accounts for the crises that occur each time the media fail to take into account those imperceptible sociocultural variables peculiar to each cultural nationality in Nigeria while reporting on issues cutting across cultures and religion.

The pluralistic theorists believe that society comprises many interacting groups having individual interests to accomplish. This is based on the assumption that the various groups in society have more or less equal access to public resources and influence. It is upon this premise that some people sometimes wonder at the complaints of the seemingly very poor members of the society on the erroneous assumption that everyone has equal opportunity and access to succeed in life. So the media being a creation of the society function mainly to represent the different segments of the society, depending on the editorial mission of the particular media concern. Most media practitioners do not make any conscious effort to evaluate the likely implications of their reports on the peace and development of society; so long they are convinced that their reports reflect the true account of an event or issue under review. For example, a polemic publication of Moslem ethics and values will lead to crisis anywhere in the world, whereas, making a disparaging comment about any other religion, could at best lead to a heated argument or debate. Therefore, media understanding the dynamics of intercultural communications, to some extent, could reduce the tempo of conflicts in society. "Several reasons exist to support face-to-face intercultural contact, compared to mediated contact, as more effective in the reduction of prejudice among people in advantaged groups. ${ }^{15}$ For individuals who perceive stereotypical beliefs as exaggerated generalizations, not based on factual information, exposure to counter-stereotypical exemplars can influence shifting attitudes."

\section{Method}

The study used the content analysis approach to evaluate the voting patterns of the Nigerian electorate in the 2015 presidential election. In addition, the paper employed the cross tabulation frequency distribution table to show the degree of support each of the presidential candidates received from his or her ethnic nationality. The cross tabulation frequency distribution table makes it easier for one to see at a glance the states as well as the geo-political regions where each of the presidential candidates won and lost in the 2015 presidential election. The unit of analysis for the study is the result of the 2015 presidential election.

\section{Voting pattern in nigerian politics}

The 2015 presidential election revealed how ethnicity and religion can influence the chances of politicians winning elections in Nigerian politics. The election campaign provided the platform for the candidates to advertise the ideologies and manifestoes of their respective parties. Former President Good luck Jonathan contested under the platform of the Peoples Democratic Party (PDP) and used the public media for his electioneering campaign, while General Muhammadu Bahari, now President of the Federal Republic of Nigeria, contested in the election under the auspices of the All Progressives Congress of Nigeria (APC) being the main opposition party in the election. The argument of the PDP in the 2015 presidential election was on the need for the Nigerian electorate to vote for President Good luck Jonathan to enable him complete the transformation agenda he started in the public and the private sectors of the nation's economy. On the other hand, the APC requested Nigerians to vote for a change of the PDP led administration to enable the citizens enjoy the dividends of democracy. ${ }^{16}$ The media provided the platforms for both candidates to advertise the changes they intend to bring into governance when elected into office. It is worth noting that General Buhari refused all the entreaties made by the Nigerian media for him to engage former President Jonathan in a public debate as it is customary in modern practice for presidential candidates explaining to the people using the forum of a public debate the changes they intend to bring into governance when elected into office.

As General Buhari refused the invitation by the media for a public debate, President Jonathan decided to unilaterally present himself and the members of his cabinet for a public debate, where each of his cabinet ministers explained to the nation the contributions they made toward the growth and development of the country while in office. Unfortunately, the effort made by President Jonathan and his cabinet could not change the negative perception that the majority of Nigerians had toward President Jonathan's administration, following the allegations of corruption leveled against some of the key members of his cabinet. Most people had expected President Jonathan to demonstrate his apathy for corruption by isolating himself from allegedly corrupt persons, and to prosecute the public officers who were indicted to have been involved in cases of gross misconduct. Unfortunately, President Jonathan was not someone who could easily be persuaded to act in line with public expectations for his government. So, he lost the 2015 Presidential election among other reasons, for associating with people that were not very favoured by the key members of the PDP. This was notwithstanding the improvements his government made in the public and the private sectors of the nation's economy. General Buhari won the 2015 Presidential because of the overwhelming support he received from the three Northern geo-political zones, including the South-West zone of Nigeria. The appointment of Professor Yemi Osinbajo as the running mate to General Buhari accounted largely for the support he received from the South-West zone of Nigeria, in addition to the common sense revolution adopted by the APC according Alhaji Asiwaju Ahmed Tinubu, former Governor of Lagos State and leader of the APC. The common sense revolution was a technique adopted by the APC whereby its candidates focused on the failures of Jonathan's administration during the election campaign without the candidates explaining to Nigerians the changes the APC government intends to enact when elected into power.

Nonetheless, General Buhari had clean reputation and integrity that could not be faulted by the members of the opposition party. He was 
a Military Head of State from December, 1983 to August, 1985. He launched an anti-corruption crusade and the War against Indiscipline (WAI) to restore dignity to public service. But a section of the media felt that General Buhari having earlier promulgated the infamous Decree No 2 and 4 of 1984 that took away the fundamental human rights of Nigerians, such a person could not have suddenly possessed the civility of a democrat to lead Nigerians in the 21 First Century. So, some arms of the Nigerian media initially doubted the candidacy of General Buhari for the office of the President of the Federal Republic of Nigeria until it became very obvious that the majority of Nigerians wanted a replacement of the PDP led administration in the country. The negative perception of the media of Buhari's inclination towards democratic principles and values may have accounted for why he decided to shun the public debate organized in his honour by the Nigerian journalists. Let us take a look at the official results of the 2015 presidential election as published by the Independent National Electoral Commission (INEC) to see how ethnicity influenced the voting patterns of the Nigerian electorate (Table 1).

Table I The analysis of the results of the 2015 Presidential in the six-geo-political zones and the FCT

\begin{tabular}{lllll}
\hline S/N & Six-geo-political zones \& the FCT & PDP & APC & Total \\
\hline 1 & FCT & $157,195(1 \%)$ & $146,399(1 \%)$ & $303,594(1 \%)$ \\
2 & North-East & $796,588(6 \%)$ & $2,848,678(18 \%)$ & $3,645,266(13 \%)$ \\
3 & North-West & $1,339,706(11 \%)$ & $7,115,199(46 \%)$ & $8,454,905(30 \%)$ \\
4 & North-Central & $1,558,623(12 \%)$ & $2,264,614(15 \%)$ & $3,823,237(14 \%)$ \\
5 & South-South & $4,714,725(37 \%)$ & $418,590(3 \%)$ & $5,133,315(18 \%)$ \\
6 & South-East & $2,464,906(19 \%)$ & $198,248(1 \%)$ & $2,663,154(9 \%)$ \\
7 & South-West & $1,821,416(14 \%)$ & $2,433,193(16 \%)$ & $4,254,609(15 \%)$ \\
Total & Six geo-political zones \& FCT & $12,853,159(100 \%)$ & $15,424,921(100 \%)$ & $28,278,080(100 \%)$ \\
\hline
\end{tabular}

\section{Discussion}

\section{Findings}

In the Federal Capital Territory (FCT), PDP polled 157,195 votes being $(1 \%)$ of the total votes earned by the PDP candidate in the 2015 presidential election, while APC received 146, 399 votes accounting for $(1 \%)$ of the total votes polled by the APC candidate. The PDP candidate received 796,588 votes in the North-East region being $(6 \%)$ of the total votes received by the PDP candidate in the election, while the APC candidate polled 2,848,678 votes being $(18 \%)$ of the total votes received by the APC candidate in the election. In the NorthWest zone, the PDP candidate polled 1, 339,706 votes (11\%) of the total votes polled by the PDP candidate in the election, while the APC candidate had $7,115,119$ votes being $(46 \%)$ of the total votes the APC candidate got in the election. In the North-Central, the PDP candidate polled $1,558,623$ votes $(12 \%)$ of the votes the PDP candidate polled in the election. The APC candidate had 2,264,614 votes being (15\%) of the total votes received by the APC candidate in the election. The PDP polled 4,714,725 votes in the South-South region being (37\%) of the votes PDP candidate polled in the election and the APC candidate had 418,590 votes $(3 \%)$ of the votes APC got in the election. In the South-East, the PDP candidate had 2,464,906 votes (19\%) of the total votes PDP candidate polled in the election, while the APC candidate polled 198,243 votes (1\%) being the total votes the candidate polled in the election. In the South-West, the PDP polled 1,821,416 votes (14\%) being the total votes the candidate polled in the election, while the APC candidate had 2,433,193 votes $(16 \%)$ of the total votes the APC candidate had in the election.

The PDP candidate, President Jonathan, had the highest number of votes in the FCT, the South-South zone and the South-East zone, while the APC candidate, General Buhari, polled the highest number of votes in the North-East, North-West, North-Central and the South-West zone. Data revealed that President Jonathan had the highest number of votes in the South-South region of Nigeria, recording 4,714,725 votes that accounted for $(37 \%)$ of the entire votes polled by President Jonathan who is an indigene of the South-South region of Nigeria. General Buhari had the highest number of votes in the North West zone, where he polled 7,115,119 votes (46\%) of the entire votes he had in the election. General Buhari is an indigene of the Fulani tribe from the North-West region. Each of the candidates that contested in the 2015 Presidential election received the highest number of votes from the states comprising the ethnic nationality/region of the candidate concern, confirming that there is a positive correlation between the chances of politicians winning elections in Nigeria and their state of origin. Based on the statistics of the last elections, it looks like a winwin situation for a Nigerian citizen of Hausa-Fulani origin contesting for the office of the President of Federal Republic of Nigeria, so long the candidate has the support of the three geo-political zones in the northern region, whereas, it is a no-win situation for a candidate from any of the three geo political zones in the southern part of Nigeria to win presidential election without the goodwill and support of the voters in the northern geo political zones. It is worth noting that $46 \%$ of the votes upon which General Buhari emerged the winner of the May 2015 presidential election were realized from the North-West geo-political zone.

\section{Media as emerging power blocs}

The media as emerging power blocs in the Nigerian politics can help to reduce the negative impact of cultural politics on the voting patterns of the Nigerian electorate. The media provide reports on election activities and write editorials on public assessment of the credibility of election results. Unfortunately, the press being an offshoot of the society seems to be incapable of providing the information framework whereupon the problem of ethnicity and religion can be solved in the Nigerian politics. This is because; the press for whatever reason is usually not able to capture the historical antecedents accounting for most of the contemporary socio-cultural conflicts in society. The media would normally write their reports on the issues and events that occur daily in society to keep citizens abreast 
of the happenings within and around their environments. Ideally, it is the responsibility of the media to educate the public on the origin of the social conflicts being reported by journalists. This is because; it is the links between the past and the present occurrences in society that give historians the insight to make intelligent predictions regarding future events. Assuming the Nigerian press is able to explain the origin of the crises currently confronting the nation, such information would have enabled the members of the public to have a balanced view of the issues being reported by the media, and then, able to make meaningful contributions toward resolving whatever conflict in the interest of peace Otete et al. ${ }^{17}$ agrees that the mass media serve as vital bridge builder (in society). Even the political conflicts arising from the conduct of elections have some elements of ethnicity when carefully examined. This was the case of the violent protest that trailed the governorship election in the South Western Nigeria during the Second Republic, where Chief Akin Omoboriowo of the National Party of Nigeria (NPN) was declared the winner of the governorship election in Ondo State instead of the actual winner of the election, Chief Adekunle Ajasin, member of the Unity Party of Nigeria. ${ }^{17}$

Constitutionally, media organizations are expected to provide objective assessment on election activities whereupon the public decides whether or not to support the results of elections as approved by the electoral commission. Lasswell 1948 Folari $^{18}$ explains the three traditional functions of the media in society, which are: surveillance of the environment being the news function of the media, correlation of the different parts of the environments, explaining the editorial function of the media and the transmission of the cultural heritage of the society from one generation to another, depicting the entertainment role of the media. Going by the above explanation, the Nigerian media have a responsibility to support an inclusive government that will accommodate both the major and the minority ethnic groups in the country. Unfortunately, the Nigerian media are not so free as to be able to objectively report on election results without first considering the stand of their proprietors on the election. The government would normally expect the public media to endorse the results of elections as approved by the electoral commission notwithstanding the claims and objections that may be arising from the elections. On the other hand, the private media operators also consider the views of their owners on election results before taking a stand on the outcome of any election so as not to contradict the views of their proprietors on the election. This is however in contrast with public expectations for journalists.

Unlike the politicians, journalists are not expected to fan the embers of cultural interests or take side with sectional groups at the detriment of public interest. But there are some media houses that are not public orientated in their news coverage as a result of external influence, which explain why the degree of objectivity of media content is usually a function of the editorial mission of the particular media outfit. The media houses operating from the perspective of the libertarian theory are likely to be more objective in their assessment of issues than media organizations having other considerations forming the basis of their editorial missions. The Nigerian media system has two types of ownership patterns (the public and the private ownership) with a preponderance of the government dominating the electronic media, while the private ownership controls the print media. The majority of the private media houses in the country are owned by Nigerian citizens of the southern extraction (Igbos, Yorubas and the indigenes of the South-South region of Nigeria). Since ownership has the potential to influence the editorial content of the media, there is the possibility that the politicians in the southern parts of the country may have more access to using the media than the citizens in other parts of the country. The implication of this is the possibility of the media setting agenda for public discussion based on the comments and actions of the Nigerian citizens living in the southern parts of the country. Therefore, it may be unfair expecting the federal government to respond to public needs based on media recommendations alone. This is because of the likelihood of the media not being able to accommodate the views of Nigerian citizens, cutting across tribes and religion regarding public assessment of government policy agenda for development.

So, it is incorrect to assume that Nigerian media would normally provide objective coverage while reporting on issues cutting across tribe and religion in the country. For example, the media have different views on the ongoing anti corruption campaign of President Buhari's administration. Virtually all the federal government owned media stations report favorably on the ongoing anti-corruption campaign by the federal government, whereas some private media organizations believed that President Buhari is fighting a war of personal vendetta against some key members of the opposition parties using the Economic and Financial Crime Commission to prosecute the war. A situation whereby media organizations that should ideally maintain the same position, condemning anti-public policies and supporting public oriented programmes, are now expressing dissenting voices on obvious national issues; certainly, it is something a rational mind should worry about. The consequences of the public and the private media in Nigeria failing to take an objective position in reporting on ethno-religious matters have the potential to convert the intermittent disagreements between the southern and northern Nigeria into a cold war similar to the relationship that exists between the United States and Russia. There is the possibility of the Nigerian media (going by the current development), later taking side with an ethnic or a religious group even at the expense of the nation. When that happens, it will be a repeat of the role the Nigerian press played culminating in the collapse of the Nigerian First Republic in January 1966.

\section{Conclusion}

In the western world, the effect of ethnicity is not as pronounced as it is in Africa. In Nigeria for example, the choice of who becomes the President of Nigeria is often decided by a group, comprising the retired generals, traditional rulers and the captains of the Nigerian industries. It is the preferred candidate of this group that subsequently emerge the winner in every election. Therefore, one tends to wonder what is democratic about the Nigerian democracy, where a few individuals can impose a candidate on a party, ignoring primaries. Ideally, it is the party executive that should organize the primaries where the most deserving candidates within the party are elected to contest in the main elections. This is not the practice in the Nigerian democracy. It thus appears that the Nigerian electorate has no choice for now of who becomes the President of the Federal Republic of Nigeria, so long ethnicity and religion remain the major considerations in the Nigerian politics. This is why this paper is recommending that the Federal Government adopts a model where the office of the President of Nigeria will be rotated among the six geo-political zones as was earlier recommended by Chief Anthony Enahoro. It could be recalled that Chief Enahoro evolved the ideology of the six geo-political zones to minimize the negative effects of the north and south dichotomy in the Nigerian politics. The present political arrangement does not appear to have made room for a fair representation by the six geopolitical zones in the office of the President of Nigeria. Therefore, while the 'brain-box' of the Nigerian politics is deciding on who becomes the next President of Nigeria after Buhari's administration, 
it is important to consider as a matter of national interest the election of a Nigerian President of an Igbo origin. This might require that the mentors of the Nigerian democracy look out for the most deserving candidates among the Igbos in all the political parties, to mentor for the office for the office of the President of Nigeria. Except for other considerations outside the pages of the Nigerian political history (pre-dating the birth of modern writers), it would be reasonable for the other ethnic nationalities in Nigeria to support the emergence of a Nigerian President of an Igbo origin after the tenure of President Muhammadu Buhari in the interest of equity and justice in power sharing in the Nigerian politics.

\section{Acknowledgements}

None.

\section{Conflict of interest}

The author declares no conflict of interest.

\section{References}

1. Ake C. Democracy and development in Africa. Nigeria: Spectrum Books Limited; 2003. 17 p.

2. Oboh GE. Mediatisation of Nigerian elections: Issues and perspectives for African democracy. Nigeria: Stirling Horden Publishers Limited; 2014. 187 p.

3. Ewhrudjakpor C, Ogege SO. Emergent social structure as consequence of multi-national oil companies activities in the Niger Delta region of Nigeria. Journal of social and management sciences. 2011;6(2):33-41.

4. Atubi AO, Oromareghake P. African regional, peace keeping (Ecowas/ Ecomog, SADC, IGAD \& AU), In: Ohwona A, et al. editors. Peace studies and conflict resolution. Nigeria: General Studies department, Delta State University; 2008. p. 55-66.

5. Hudson R. Conflict, identity, and the Internet: Use of the Internet by Serbian intelligentsia during the 1999 Kosovo conflict. Journal of communication and media research. 2010;2(1):1-16.

6. Anugwom EE. Cultural differences in negotiation. In: Best SG, editor. Introduction to peace and conflict studies in West Africa. Nigeria: Spectrum Books Limited; 2009. p. 142-158.
7. Omu FIA. Ethnicity, Nationalism and Federalism in Nigeria: An interactive trinity relationship. In: Omu FIA, Oboh GE, editors. Mass media in Nigerian democracy. Nigeria: Stirling Horden Publishers Limited; 2008. p. 88-115.

8. Okechukwu E. Transnational political identity in Russia: An examination of micro nationalism in Ossetia and Abkazia. International journal of communication: An interdisciplinary journal of communication studies. 2008;9:358-374.

9. Gray K, Cheong PH. Mediating intercultural dialectics: Identity perceptions and performances in virtual worlds. Journal of international and intercultural communication. 2011;4(4):263-271.

10. Dioka LC. Inter group relations among Nigerian communities. In: Osuntokun A, Olukoju A, editors. Nigerian peoples and cultures. Nigeria: University of Lagos; 1997. p. 56-79.

11. Manderson D. Pop cult, hi tech and the irony of tradition. Cultural Studies. 2013;27(1):11-29.

12. McEwan B, Sobre Denton M. Virtual cosmopolitanism: Constructing Third cultures and transmitting social and cultural capital through social media. Journal of international and intercultural communication. 2011;4(4):252-258.

13. Balnaves M, Donald SH, Shoesmith B. Media, theories and approaches: A global perspective. USA: Palgrave Macmillian; 2009.

14. Kaylor BT. Just a little talk with Jesus: The portrayal of Jesus in NBC's The Book of Daniel. Journal of media and religion. 2011;10(3):138-151.

15. Ramasubramanian S. Inter group contact, media exposure, and racial attitudes. Journal of international communication research. 2013;42(1):54-72.

16. Akpoveta EE. Communication as a tool for sustainable rural development. International journal of communication: An interdisciplinary journal of communication studies. 2006;4:205-216.

17. Otete A, Obagbinoko C. Root causes of conflicts in Africa. In: Ohwona A, et al. editors. Peace studies and conflict resolution. Nigeria: General Study's department, Delta State University; 2008. p. 12-21.

18. Folari B. Theories of mass communication: An introductory text. Nigeria: Link Publications; 2002. 